E-JURNAL EKONOMI DAN BISNIS UNIVERSITAS UDAYANA
Available online at https://ojs.unud.ac.id/index.php/EEB/index
Vol. 10 No. 09, September 2021, pages: 751-760
e-ISSN: 2337-3067

\title{
ANALISIS FAKTOR-FAKTOR YANG MEMPENGARUHI PENGANGGURAN DI KABUPATEN/KOTA WILAYAH SARBAGITA
}

\author{
Putu Nanda Haribawani ${ }^{1}$ Ida Ayu Nyoman Saskara ${ }^{2}$
}

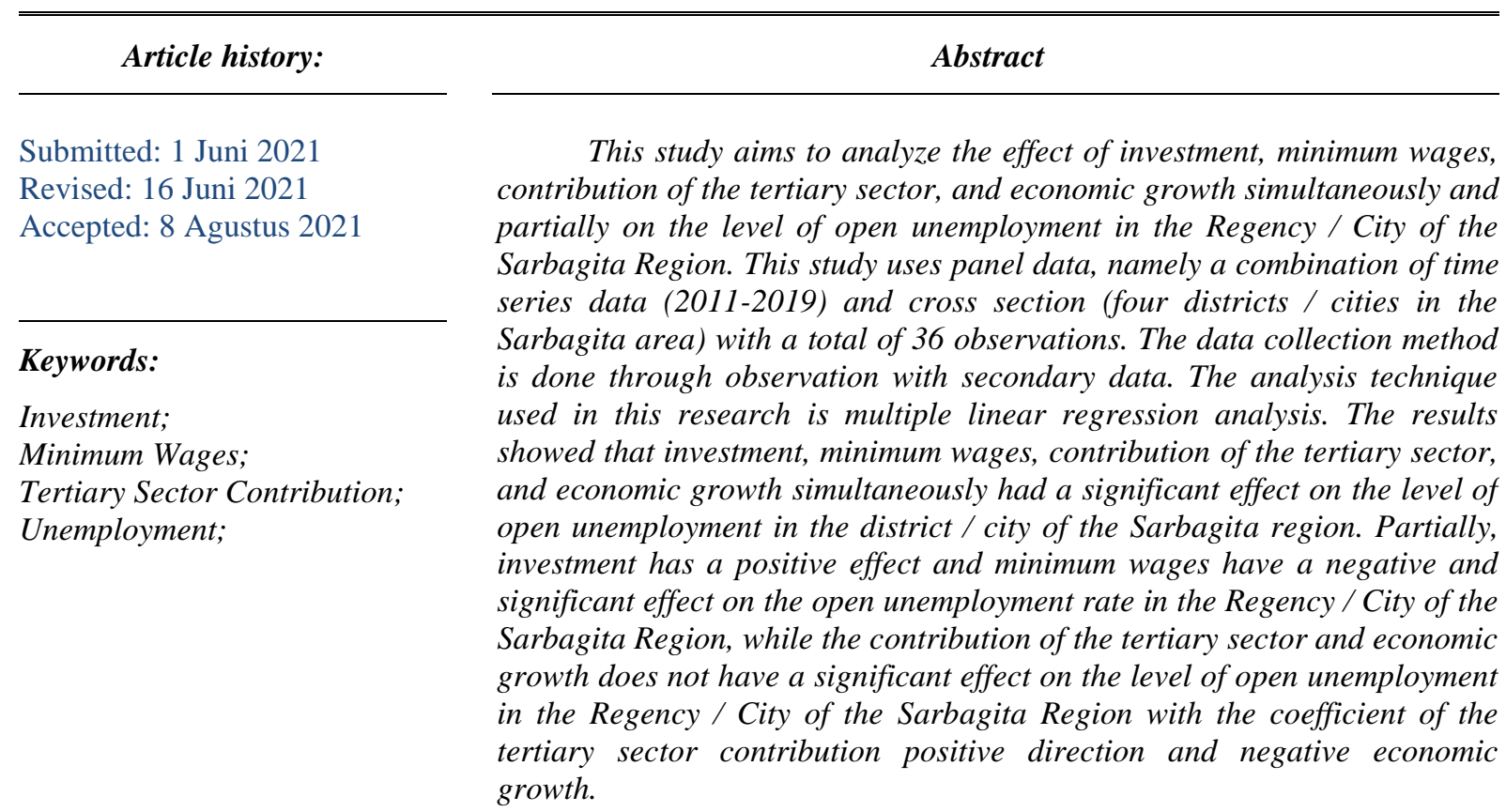

\section{Kata Kunci:}

Investasi;

Upah Minimum;

Kontribusi Sektor Tersier;

Pengangguran;

\section{Koresponding: \\ Fakulas Ekonomi dan Bisnis \\ Universitas Udayana, Bali, \\ Indonesia \\ Email: \\ nandraharbawani@gmail.com}

\section{Abstrak}

Penelitian ini bertujuan untuk menganalisis pengaruh investasi, upah minimum, kontribusi sektor tersier, dan pertumbuhan ekonomi secara simultan dan parsial terhadap tingkat pengangguran terbuka di Kabupaten/Kota Wilayah Sarbagita. Penelitian ini menggunakan data panel yaitu gabungan dari data time series (2011-2019) dan cross section (empat kabupaten/kota di wilayah Sarbagita) dengan jumlah pengamatan sebanyak 36 pengamatan. Metode pengumpulan data dilakukan melalui observasi dengan data sekunder. Teknik analisis yang digunakan dalam penelitian ini yaitu teknik analisis regresi linear berganda. Hasil penelitian menunjukkan bahwa investasi, upah minimum, kontribusi sektor tersier, dan pertumbuhan ekonomi secara simultan berpengaruh signifikan terhadap tingkat pengangguran terbuka di Kabupaten/Kota Wilayah Sarbagita. Secara parsial, investasi berpengaruh positif dan upah minimum berpengaruh negatif serta signifikan terhadap tingkat pengangguran terbuka di Kabupaten/Kota Wilayah Sarbagita, sedangkan kontribusi sektor tersier dan pertumbuhan ekonomi tidak berpengaruh signifikan terhadap tingkat pengangguran terbuka di Kabupaten/Kota Wilayah Sarbagita dengan koefisien variabel kontribusi sektor tersier berarah positif dan pertumbuhan ekonomi berarah negatif.

Fakultas Ekonomi dan Bisnis Universitas Udayana, Bali, Indonesia ${ }^{2}$

Email: saskara@unud.ac.id 


\section{PENDAHULUAN}

Pengangguran merupakan salah satu permasalahan besar yang terjadi di seluruh negara, termasuk Indonesia. Margareni (2016) berpendapat bahwa masalah pengangguran penting untuk diperhatikan karena akan berdampak pada peningkatan pengangguran sehingga akan menimbulkan kekacauan sosial dan politik dan akan mempengaruhi kesejahteraan masyarakat dan pembangunan ekonomi jangka panjang. Menurut Sukirno dalam Hartanto (2017) pengangguran memiliki efek yang buruk bagi perekonomian dan masyarakat, karena dapat mempengaruhi dan dipengaruhi oleh beberapa faktor yang saling berinteraksi. Pengangguran memiliki potensi terjadinya Tindakan criminal dan gejolak sosial (Chang \& Wu, 2012). Di Provinsi Bali, masalah pengangguran merupakan isu penting yang menjadi permasalahan ketenagakerjaan dalam pembangunan ekonomi. Berdasarkan data dari Badan Pusat Statistik, perkembangan pengangguran di Provinsi Bali terus berfluktuasi dari tahun 2011-2019. Tingkat pengangguran tertinggi di Provinsi Bali terjadi pada tahun 2011, yaitu sebesar 2,95 persen dengan daerah yang memiliki pengangguran tertinggi berada di Kota Denpasar sebesar 4,56 persen dan tingkat pengangguran terendah terjadi pada tahun 2018 sebesar 1,37 persen. Tingkat Pengangguran Terbuka (TPT) di Provinsi Bali pada tahun 2019 sebesar 1,52 persen, jumlah ini meningkat setinggi 0,15 poin dibandingkan TPT pada tahun 2018 yang tercatat sebesar 1,37 persen dan Kabupaten Badung merupakan daerah dengan tingkat pengangguran terendah yaitu sebesar 0,38 persen, sedangkan tingkat pengangguran tertinggi terjadi di Kabupaten Buleleng sebesar 3,02 persen, yang kemudian diikuti oleh Kota Denpasar yang memiliki tingkat pengangguran tertinggi kedua yaitu sebesar 2,22 persen.

Kota Denpasar dan Kabupaten Badung merupakan daerah yang termasuk ke dalam Wilayah Sarbagita, selain Kabupaten Gianyar dan Tabanan. Wilayah Sarbagita merupakan wilayah berintegrasi dan wilayah metropolitan yang menjadi wilayah percontohan dalam pembangunan dan kesejahteraannya paling tinggi, namun pada kenyataannya tidak diikuti dengan tingkat pengangguran yang rendah, kecuali Kabupaten Badung. Terdapat beberapa faktor yang dapat mempengaruhi tingkat pengangguran di wilayah Sarbagita, seperti investasi, upah minimum, kontribusi sektor ekonomi, dan pertumbuhan ekonomi. Yusuf \& Sumner (2015) menyebutkan bahwa investasi pada suatu daerah dapat mempengaruhi jumlah pengangguran. Adanya investasi akan mendorong pertumbuhan ekonomi dan secara efektif mengurangi kerimpangan pada kemiskinan, dan memberikan kontribusi dalam mengakses peluang kerja. Dalam peningkatan pertumbuhan ekonomi, investasi dapat membantu menciptakan lapangan pekerjaan sehingga akan terjadi penurunan pengangguran (Indranjoto \& Dewi, 2014).

Seran (2017) mengemukakan bahwa tingkat upah yang berlaku di daerah dapat mempengaruhi jumlah pengangguran, karena tenaga kerja lebih memilih tidak bekerja dibandingkan bekerja karena tangkat upah yang rendah, yang kemudian disebut pengangguran sukarela. Hubungan antara upah minimum dengan pengangguran dapat dijelaskan melalui teori kekakuan upah, dimana upah tidak selalu bisa fleksibel atau tidak bisa melakukan penyesuaian sampai penawaran tenaga kerja sama dengan permintaannya. Tingkat upah yang tinggi akan dapat memberikan dampak pada peningkatan produktivitas, karena akan merangsang dan memotivasi para pekerja untuk dapat memenuhi kebutuhan keluarganya dengan baik (Nurfiat \& Rustariyuni, 2018). Faktor lainnya yang dapat berpengaruh terhadap pengangguran adalah oleh perkembangan dan kontribusi sektor ekonominya terhadap Produk Domestik Regional Bruto (PDRB). Sukirno (2005) menjelaskan bahwa berdasarkan lapangan usaha sektor-sektor ekonomi dalam perekonomian Indonesia dibedakan dalam tiga kelompok utama yaitu: sektor primer, sektor sekunder dan sektor tersier. Sektor pariwisata 
merupakan sektor yang memberikan sumbangan terbesar bagi PDRB Provinsi Bali. Menurut Suryahadi et al (2012) pertumbuhan pesat industri perbankan dan perhotelan serta sektor informal yang berkembang pesat menyebabkan saat ini sektor jasa (tersier) menyumbang bagian terbesar dari PDB dan lapangan kerja.

Pertumbuhan ekonomi dan pengangguran memiliki hubungan yang saling bergantung dimana pertumbuhan ekonomi yang melebihi pertumbuhan produktivitas tenaga kerja maka lapangan kerja akan meningkat dan pengangguran akan menurun (Nikolli, 2014). Secara teoritis hubungan pengangguran dan pertumbuhan ekonomi dapat dilihat dari dua sisi, pengangguran cenderung mengurangi pertumbuhan ekonomi, dan pertumbuhan ekonomi dapat mengurangi pengangguran tenaga kerja. Menganggur cenderung akan mengurangi output per kapita dan pertumbuhan ekonomi sehingga akan meningkatkan kemiskinan. Di sisi lain, semakin tinggi PDRB maka pertumbuhan ekonomi juga meningkat.

\section{METODE PENELITIAN}

Desain penelitian ini merupakan penelitian asosiatif yang bersifat kausal. Penelitian ini dilakukan di Kabupaten/Kota Wilayah Sarbagita yaitu Kota Denpasar, Kabupaten Badung, Gianyar, dan Tabanan, karena merupakan wilayah metropolitan sehingga menjadi percontohan dalam pembangunan dan kesejahteraan paling tinggi di Provinsi Bali. Objek penelitian ini adalah pengangguran di Kabupaten/Kota Wilayah Sarbagita yang dipengaruhi oleh beberapa faktor seperti investasi, upah minimum, kontribusi sektor tersier, dan pertumbuhan ekonomi, yang terdiri dari 4 kabupaten/kota dalam rentang waktu 9 tahun yaitu tahun 2011-2019. Jenis data yang digunakan dalam penelitian ini adalah data kuantitatif yaitu data panel merupakan gabungan dari data runtut waktu (time series) tahun 2011-2019 dan data silang (cross section) data empat kabupaten/kota yang termasuk ke dalam Wilayah Sarbagita. Data kualitatif dalam penelitian diperoleh dari penelitian sebelumnya, artikel, buku, literature lainnya terutama yang terdapat teori-teori yang berkaitan dengan variabel dalam penelitian. Adapun jumlah pengamatan dalam penelitian yaitu sebanyak 36 pengamatan. Metode pengumpulan data yang digunakan dalam penelitian ini adalah observasi, yang dilakukan melalui penelusuran data sekunder dari lembaga yang sesuai dengan variabel-variabel yang di bahas dalam penelitian ini, seperti Badan Pusat Statistik (BPS) Provinsi Bali, BPS Kota Denpasar, BPS Kabupaten Badung, BPS Kabupaten Gianyar, dan BPS Kabupaten Tabanan. Teknik analisis data yang digunakan yaitu analisis regresi linier berganda.

\section{HASIL DAN PEMBAHASAN}

Investasi dapat diartikan sebagai pengeluaran atau pembelanjaan penanam-penanam modal atau perusahaan untuk membeli barang-barang modal dan perlengkapan-perlengkapan produksi untuk menambah kemampuan memproduksi barang-barang dan jasa-jasa yang tersedia dalam perekonomian. Berdasarkan hasil penelitian diketahui bahwa pertumbuhan investasi di kabupaten/kota wilayah sarbagita berfluktuasi dan cenderung mengalami penurunan dari tahun 2011-2019 jika dilihat dari nilai Pembentukan Modal Tetap Domestik Bruto (PMTDB). Pertumbuhan investasi tertinggi di kabupaten/kota wilayah sarbagita terjadi pada tahun 2011 yaitu berada di atas kisaran 10 persen dengan Pertumbuhan PMTDB tertinggi terjadi di Kabupaten Badung sebesar 15,88 persen, kemudian diikuti oleh Kota Denpasar pada posisi kedua sebesar 15,84 persen, Kabupaten Tabanan di posisi

Analisis Faktor-Faktor Yang Mempengaruhi Pengangguran Di Kabupaten/Kota Wilayah Sarbagita, Putu Nanda Haribawani dan Ida Ayu Nyoman Saskara 
ketiga sebesar 13,30 persen dan diposisi keempat yaitu Kabupaten Gianyar sebesar 12,28 persen. Pertumbuhan investasi ini kemudian mengalami penurunan setiap tahunnya sampai pada tahun 2014 menjadi tahun dengan pertumbuhan PMTDB terendah yang berada dibawah kisaran 4 persen dan Kabupaten Badung memiliki pertumbuhan investasi terendah yaitu sebesar 0,42 persen dibandingkan dengan kabupaten/kota wilayah sarbagita lainnya. Pertumbuhan investasi ini kemudian mengalami peningkatan pada tahun 2015 dan 2016 tapi hanya berada dibawah kisaran 10 persen, namun pertumbuhan ini kembali mengalami penurunan di tahun 2017 dan meningkat kembali pada tahun 2018. Pada tahun 2019 pertumbuhan investasi di kabupaten/kota wilayah sarbagita kembali mengalami penurunan dari tahun sebelumnya, dengan pertumbuhan investasi tertinggi di Kabupaten Gianyar sebesar 4,82 persen, sedangkan yang terendah di Kabupaten Badung yaitu 4,11 persen.

Upah minimum adalah suatu standar minimum yang digunakan oleh para pengusaha atau pelaku industri untuk memberikan upah kepada pekerja di dalam lingkungan usaha atau kerjanya. Berdasarkan hasil penelitian diketahui bahwa upah minimum kabupaten/kota wilayah sarbagita dari tahun 2011-2019 terus mengalami peningkatan setiap tahunnya. Upah minimum kabupaten/kota terendah pada tahun 2011 berada di Kabupaten Tabanan yaitu sebesar Rp 910.000,-, kemudian diikuti dengan Kabupaten Gianyar sebesar Rp 1.003.625,-, Kota Denpasar sebesar Rp 1.191.500,- dan UMK tertinggi pada tahun 2011 yaitu Kabupaten Badung sebesar Rp 1.221.000,-. Hingga tahun 2019 upah minimum terus mengalami peningkatan dengan UMK tertinggi yaitu di Kabupaten Badung sebesar Rp 2.700.297,-- sedangkan UMK terendah yaitu di Kabupaten Tabanan sebesar Rp 2.419.332,-. Empat Kabupaten/kota wilayah sarbagita merupakan daerah yang memiliki upah minimum tertinggi di Provinsi Bali dibandingkan dengan kabupaten lainnya.

Struktur perekonomian kabupaten/kota wilayah sarbagita di dominasi oleh sektor tersier atau jasa yang dipengaruhi oleh perkembangan pariwisata di wilayah tersebut. Berdasarkan hasil penelitian diketahui bahwa dari tahun 2011-2019 kontribusi sektor tersier di Kabupaten/Kota Wilayah Sarbagita mengalami fluktuasi dan cenderung mengalami peningkatan. Kontribusi sektor tersier terhadap PDRB yang tertinggi terjadi Kabupaten Badung dibandingkan 3 kabupaten/kota wilayah sarbagita lainnya. Kontribusi sektor tersier terendah terjadi pada tahun 2012 di Kabupaten Tabanan sebesar 58,42 persen. Pada tahun 2019 kontribusi sektor tersier terbesar terdapat di Kabupaten Badung sebesar 78,00 persen kemudian diikuti Kota Denpasar pada urutan kedua sebesar 76,00 persen, di posisi ketiga terdapat Kabupaten Gianyar dengan kontribusi sektor tersier sebesar 63,34 persen, dan Kabupaten Tabanan menepati urutan keempat dengan kontribusi sektor tersier sebesar 61,84 persen. Kontribusi sektor tersier yang tinggi di atas kisaran 50 persen ini menunjukkan bahwa sebagai besar perekonomian di Kabupaten/Kota Wilayah Sarbagita bergantung pada sektor tersier.

Pertumbuhan ekonomi menunjukkan sejauh mana aktivitas perekonomian akan menghasilkan tambahan pendapatan masyarakat pada suatu periode tertentu (Kusumawati \& Wiksuana, 2018). Berdasarkan hasil penelitian diketahui bahwa kabupaten/kota di Wilayah Sarbagita memiliki pertumbuhan ekonomi yang berfluktuasi dan cenderung menurun dari tahun 2011-2019. Pada tahun 2011 pertumbuhan ekonomi di wilayah sarbagita berada pada kisaran 7 dan 6 persen dengan pertumbuhan ekonomi tertinggi berada di Kota Denpasar sebesar 7,16 persen dan terendah berada di Kabupaten Tabanan sebesar 6,11 persen. Pada tahun 2019 pertumbuhan ekonomi di wilayah sarbagita mengalami penurunan dan berada di kisaran 5 persen dengan pertumbuhan ekonomi tertinggi berada di Kota Denpasar sebesar 5,84 persen. Kota Denpasar, Kabupaten Badung, Kabupaten Gianyar, dan Kabupaten Tabanan atau yang sering disebut wilayah Sarbagita merupakan lokasi pariwisata yang menjadi perhatian wisatawan domestik ataupun internasional. Oleh karena itu, empat kabupaten/kota di wilayah Sarbagita merupakan daerah dengan pertumbuhan ekonomi tertinggi dan memiliki peran

Analisis Faktor-Faktor Yang Mempengaruhi Pengangguran Di Kabupaten/Kota Wilayah Sarbagita, Putu Nanda Haribawani dan Ida Ayu Nyoman Saskara 
yang sangat besar dalam menunjang pertumbuhan ekonomi di Provinsi Bali, akan tetapi wilayah ini mengakibatkan ketimpangan di beberapa kabupaten/kota lainnya.

Berdasarkan hasil penelitian diketahui bahwa tingkat pengangguran terbuka di Kabupaten/Kota wilayah Sarbagita yang berfluktuasi dari tahun 2011-2019. Kota Denpasar pada tahun 2011-2019 merupakan daerah yang memiliki angka TPT tertinggi diantara kabupaten wilayah Sarbagita lainnya, dimana pada tahun 2011 angka TPT Kota Denpasar sebesar 4,56 persen. Pada tahun 2019, angka TPT tertinggi terdapat di Kota Denpasar sebesar 2,22 persen yang meningkat sebesar 0,4 persen dari tahun sebelumnya (tahun 2018), sedangkan TPT terendah terdapat di Kabupaten Badung sebesar 0,38 persen. Berbeda dengan Kota Denpasar yang angka tingkat penganggurannya pada tahun 2019 mengalami peningkatan, kabupaten lainnya di wilayah Sarbagita justru mengalami penurunan dari tahun sebelumnya. Tahun 2019 TPT Kabupaten Badung mengalami penurunan sebesar 0,06 persen dari tahun sebelumnya, TPT Kabupaten Gianyar menurun 0,18 persen dari tahun 2018 menjadi 1,42 persen, dan TPT Kabupaten Tabanan sebesar 1,28 persen yang menurun sebesar 0,15 persen dari tahun sebelumnya. Adanya pengangguran terbuka di suatu daerah mengindikasikan masih terdapat masyarakat yang belum optimal memanfaatkan kemampuannya untuk berpartisipasi aktif dalam dunia kerja.

Tabel 1.

Hasil Analisis Statistik Deskriptif

\begin{tabular}{cccccc}
\hline & Investasi & $\begin{array}{c}\text { Upah } \\
\text { Minimum }\end{array}$ & $\begin{array}{c}\text { Kontribusi } \\
\text { Sektor Tersier }\end{array}$ & $\begin{array}{c}\text { Pertumbuhan } \\
\text { Ekonomi }\end{array}$ & $\begin{array}{c}\text { Tingkat } \\
\text { Pengangguran }\end{array}$ \\
\hline Mean & 7,07 & 1771701 & 68,53 & 6,43 & 1,72 \\
Median & 6,56 & 1764000 & 68,73 & 6,37 & 1,76 \\
Maximum & 15,88 & 2700297 & 78 & 7,64 & 4,56 \\
Minimum & 0,42 & 910000 & 58,42 & 5,37 & 0,05 \\
Std. Dev. & 3,60 & 506374,7 & 7,94 & 0,57 & 0,93 \\
Skewness & 0,65 & 0,01 & $-0,01$ & 0,10 & 0,53 \\
Kurtosis & 3,31 & 1,82 & 1,10 & 2,23 & 3,90 \\
Jerque-Bera & 2,75 & 2,05 & 5,39 & 0,95 & 3,97 \\
Probability & 0,25 & 0,35 & 0,06 & 0,62 & 0,33 \\
Sum & 254,65 & 637812336 & 2467,41 & 231,64 & 63,08 \\
Sum Sq. Dev & 453,67 & $8,97 \mathrm{E}+12$ & 2208.90 & 11,61 & 30,09 \\
Observations & 36 & 36 & 36 & 36 & 36 \\
\hline
\end{tabular}

Sumber: Hasil Olah Data EViews 10, 2021

Berdasarkan hasil analisis diketahui bahwa jumlah pengamatan pada penelitian ini adalah 36 pengamatan (observations) yang merupakan data panel dengan data time series (kurun waktu) selama 2011-2019 (9 tahun) dan data cross section 4 kabupaten/kota wilayah Sarbagita. Variabel investasi (X1) memiliki nilai terendah (minimum) sebesar 0,420000 persen, terjadi pada tahun 2014 di Kabupaten Badung dan nilai tertinggi (maksimum) sebesar 15,88000 persen terjadi pada tahun 2011 di Kabupaten Badung. Nilai rata-rata (mean) investasi yaitu 7,073611 dengan standar deviasi yaitu 3,600283, hal ini menunjukkan bahwa data pada variabel investasi dapat menggambarkan seluruh variabel dengan kondisi baik.

Variabel upah minimum (X2) memiliki nilai terendah (minimum) sebesar 910.000,0 dan nilai tertinggi (maksimum) sebesar 2.700.297. Nilai rata-rata (mean) variabel upah minimum sebesar 1.771. 701 dengan standar deviasi yaitu 506.374,7 hal ini menunjukkan data pada variabel upah mínimum dapat menggambarkan seluruh variabel dengan kondisi baik. Variabel kontribusi sektor tersier (X3) memiliki nilai terendah (minimum) sebesar 58,42000 dan nilai tertinggi (maksimum) sebesar 78,00000. Nilai rata-rata (mean) variabel kontribusi sektor tersier adalah 68,53917 dengan standar deviasi yaitu 7,944270, hal ini menunjukkan bahwa data pada variabel kontribusi sektor tersier 
dapat menggambarkan seluruh variabel dengan kondisi baik. Variabel pertumbuhan ekonomi (X4) memiliki nilai terendah (minimum) sebesar 5,370000 dan nilai tertinggi (maksimum) sebesar 7,640000. Nilai rata-rata (mean) variabel pertumbuhan ekonomi adalah 6,434444 dengan standar deviasi 0,576048, hal ini menunjukkan bahwa seluruh data pada variabel pertumbuhan ekonomi dapat menggambarkan seluruh variabel dengan kondisi baik. Variabel tingkat pengangguran (Y) memiliki nilai terendah (minimum) sebesar 0,050000 dan nilai tertinggi (maksimum) sebesar 4,560000. Nilai rata-rata (mean) variabel tingkat pengangguran adalah 1,724444 dengan standar deviasi 0,939646 hal ini menunjukkan bahwa data pada variabel tingkat pengangguran dapat menggambarkan seluruh variabel dengan kondisi baik.

\section{Tabel 2 Hasil Uji Chow}

\section{Redudant Fixed Effects Tests Equation : Untiled \\ Test cross-section fixed effects}

\begin{tabular}{cccc}
\hline Effect Test & Statistic & d.f. & Prob. \\
\hline Cross-section F & $\mathbf{1 9 , 6 7 7 6 2 6}$ & $\mathbf{3 , 2 8})$ & $\mathbf{0 . 0 0 0 0}$ \\
Cross-section Chi- & $\mathbf{4 0 , 8 2 6 4 8 0}$ & $\mathbf{3}$ & $\mathbf{0 . 0 0 0 0}$ \\
Square & & & \\
\hline
\end{tabular}

Sumber: Hasil Olah Data EViews 10, 2021

Hasil pengujian dengan Uji Chow menunjukkan bahwa nilai probabilitas Cross-section Chi-square sebesar 0,0000 lebih kecil dari $0,05(0,000<0,05)$, hal ini model yang tepat dan terbaik digunakan untuk melakukan uji regresi dalam penelitian ini adalah fixed effect model.

Uji asumsi klasik dilakukan agar tidak terjadi penyimpangan yang cukup serius dari asumsi-asumsi yang harus dipenuhi dalam metode Ordinary Least Square (OLS). Uji asumsi klasik yang dilakukan pada penelitian ini yaitu uji multikolinearitas dan uji heteroskedastisitas. Uji Multikolinieritas bertujuan untuk menguji apakah pada model regresi ditemukan korelasi antara variabel bebas (Utama, 2016). Berdasarkan hasil pengujian diketahui bahwa nilai korelasi antara variabel bebas dalam penelitian ini lebih kecil dari 0,7 (nilai korelasi < 0,7) sehingga dapat disimpulkan bahwa tidak terjadi masalah multikolinearitas pada variabel penelitian ini. Uji Heteroskedasitas bertujuan untuk menguji apakah dalam model regresi terjadi ketidaksamaan varian dari residual satu pengamatan yang lain, yang diuji dengan menggunakan uji Glejser. Berdasarkan hasil uji heteroskedastisitas diketahui bahwa nilai probability variabel bebas dalam penelitian ini yang terdiri dari investasi (X1) sebesar 0,4274, upah minimum (X2) sebesar 0,6650, kontribusi sektor tersier sebesar 0,2981, dan pertumbuhan ekonomi (X4) sebesar 0,9324 lebih besar dari 0,05. Hal ini berarti bahwa nilai probability $>0,05$ maka dapat disimpulkan tidak terjadi gejala heteroskedastisitas dalam model penelitian ini.

Tabel 3

Hasil Analisis Regresi Linear Berganda

\begin{tabular}{lllll}
\hline Variabel & Cofficient & Std. Error & t-Statistic & Prob. \\
\hline $\mathrm{C}$ & $-0,271$ & 12,195 & $-0,022$ & 0.9824 \\
Investasi & 0,074 & 0,027 & 2,663 & 0.0127 \\
Upah Minimum & $-9,67 \mathrm{E}-07$ & $4,38 \mathrm{E}-07$ & $-2,208$ & 0.0356 \\
Kontribusi Sektor & 0,076 & 0,179 & 0,424 & 0.6747 \\
Tersier & & & & \\
Pertumbuhan & $-0,318$ & 0,277 & $-1,149$ & 0.2599 \\
Ekonomi & & & & \\
\hline
\end{tabular}

Sumber: Hasil Olah Data EViews 10, 2021 
Berdasarkan hasil analisis regresi linear berganda dengan EViews 10 yang ditunjukkan oleh tabel 4.10, maka diperoleh persamaan model regresi sebagai berikut:

$$
\hat{Y}=-0,271531+0,074430 \mathrm{X}_{1}-9,67 \mathrm{E}-07 \mathrm{X}_{2}+0,076336 \mathrm{X}_{3}-0,318547 \mathrm{X}_{4}
$$

Dari hasil pengolahan data menggunakan EViews 10 diperolah nilai adjusted $\mathrm{R}$-square sebesar 0,724488 atau 72,45 persen, artinya 72,45 persen dari total variasi (naik turunnya) tingkat pengangguran terbuka (Y) di kabupaten/kota wilayah Sarbagita dapat dijelaskan atau dipengaruhi oleh investasi $\left(\mathrm{X}_{1}\right)$, upah minimum $\left(\mathrm{X}_{2}\right)$, kontribusi sektor tersier $\left(\mathrm{X}_{3}\right)$, dan pertumbuhan ekonomi $\left(\mathrm{X}_{4}\right)$, sedangkan 27,55 persen sisanya dipengaruhi oleh faktor atau variabel lain yang tidak dimasukkan dalam model penelitian.

Hasil analisis uji statistik yaitu Uji $F$ diperoleh nilai $F_{\text {hitung }}$ sebesar $14,14803 \geq F_{\text {tabel }}$ sebesar 2,90 dan nilai signifikansi sebesar $0,000000 \leq \alpha$ dengan $\alpha=0,05$, artinya variabel investasi $\left(\mathrm{X}_{1}\right)$, upah minimum $\left(\mathrm{X}_{2}\right)$, kontribusi sektor tersier $\left(\mathrm{X}_{3}\right)$, dan pertumbuhan ekonomi $\left(\mathrm{X}_{4}\right)$ secara simultan berpengaruh signifikan terhadap tingkat pengangguran terbuka (Y) di Kabupaten/Kota Wilayah Sarbagita.

Berdasarkan hasil pengujian diperoleh nilai t-hitung sebesar 2,663433 > t-tabel sebesar 1,69389 dan nilai probabilitas signifikansi sebesar $0,0127 \leq 0,05$, yang berarti variabel investasi secara parsial berpengaruh dan signifikan terhadap tingkat pengangguran terbuka di Kabupaten/Kota Wilayah Sarbagita. Koefisien regresi variabel investasi yang bernilai sebesar 0,074430 berarti hubungan antara investasi dengan tingkat pengangguran bersifat positif. Hal ini tidak sesuai dengan hipotesis awal penelitian yang menyatakan bahwa investasi memiliki hubungan negatif terhadap tingkat pengangguran, karena berdasarkan koefisiennya yang bernilai positif berarti bahwa semakin tinggi investasi maka semakin tinggi tingkat pengangguran terbuka di kabupaten/kota wilayah Sarbagita. Hasil penelitian memiliki perbedaan dengan teori yang ada, dimana Teori Harrod Domar yang mengemukakan bahwa investasi tidak hanya menciptakan permintaan tetapi juga memperbesar kapasitas produksi (Prayuda \& Henny, 2016). Namun, hasil penelitia ini sejalan dengan penelitian Suwandika \& Yasa (2015) yang menyatakan investasi berpengaruh positif dan signifikan terhadap tingkat pengangguran di kabupaten/kota Provinsi Bali.Perbedaan arah hubungan pada hasil dengan hipotesis ini dapat disebabkan karena investasi fisik atau pembentukan modal tetap domestik bruto yang dominan berada di kabupaten/kota wilayah Sarbagita ini dipengaruhi oleh sektor pariwisata yang menjadi sektor utama dalam perekonomian daerah tersebut (Ratih dkk, 2017).

Berdasarkan hasil pengujian diperoleh nilai t-hitung sebesar 2,208611 > t-tabel sebesar 1,69389 dan nilai probabilitas signifikansi sebesar $0,0356 \leq 0,05$ yang berarti variabel upah minimum secara parsial berpengaruh negatif dan signifikan terhadap tingkat pengangguran terbuka di Kabupaten/Kota Wilayah Sarbagita. Koefisien regresi variabel upah minimum sebesar -9,67E-07 berarti hubungan antara upah minimum dan tingkat pengangguran bernilai negatif yang mempunyai arti bahwa semakin tinggi upah minimum maka semakin rendah tingkat pengangguran terbuka di kabupaten/kota wilayah Sarbagita. Hasil penelitian ini sesuai dengan Kurva Philips yang menyatakan upah memiliki hubungan yang negatif dengan pengangguran (Ummatin, 2020). Hal ini sejalan dengan penelitian Rahmah \& Murgianto (2016) yang menemukan bahwa upah minimum mempunyai hubungan yang negatif terhadap tingkat pengangguran di Kota Surabaya. Hal ini menjelaskan bahwa setiap kenaikan upah minimum maka tingkat pengangguran akan menurun. Hasil penelitian Megantara \& Budhi (2020) juga menunjukan bahwa upah minimum berpengaruh negatif dan signifikan terhadap tingkat pengangguran kabupaten/kota di Provinsi Bali.

Analisis Faktor-Faktor Yang Mempengaruhi Pengangguran Di Kabupaten/Kota Wilayah Sarbagita, Putu Nanda Haribawani dan Ida Ayu Nyoman Saskara 
Berdasarkan hasil pengujian diperoleh nilai t-hitung sebesar $0,424101<\mathrm{t}$-tabel sebesar 1,69389 dan nilai probabilitas signifikansi sebesar $0.6747>0,05$ yang berarti variabel kontribusi sektor tersier secara parsial tidak berpengaruh nyata terhadap tingkat pengangguran terbuka di Kabupaten/Kota Wilayah Sarbagita. Koefisien regresi variabel kontribusi sektor tersier sebesar 0,076336 menunjukkan bahwa hubungan antara kontribusi sektor tersier dan tingkat pengangguran bernilai positif berarti bahwa semakin tinggi kontribusi sektor tersier maka semakin tinggi tingkat pengangguran terbuka di kabupaten/kota wilayah Sarbagita. Hasil penelitian ini tidak sesuai dengan hipotesis yang menyatakan kontribusi sektor tersier secara parsial berpengaruh negatif dan signifikan terhadap tingkat pengangguran. Hal ini disebabkan karena peningkatan kontribusi sektor tersier setiap tahunnya terhadap PDRB tidak selalu diikuti dengan peningkatan penyerapan tenaga kerja pada sektor tersebut dan proses produksi pada sektor tersier cenderung bersifat padat modal yang tidak banyak menyerap tenaga kerja sehingga tidak mampu mengatasi tingkat pengangguran yang ada di kabupaten/kota wilayah Sarbagita. Hal ini didukung oleh hasil penelitian Wahyuningsih (2009) mengenai hubungan kontribusi sektor terhadap PDRB dan penyerapan tenaga kerja di Maluku meskipun kontribusi sektor terhadap PDRB yang terbesar adalah sektor tersier, namun penyerapan tenaga kerja yang terbesar bukanlah sektor tersier melainkan sektor primer.

Berdasarkan hasil pengujian diperoleh nilai t-hitung sebesar 1,149969 < t-tabel sebesar 1,69389 dan nilai probabilitas signifikansi sebesar 0,2599>0,05 yang berarti variabel pertumbuhan ekonomi secara parsial tidak berpengaruh nyata terhadap tingkat pengangguran terbuka di Kabupaten/Kota Wilayah Sarbagita. Koefisien regresi variabel pertumbuhan ekonomi sebesar 0,318547 menunjukkan bahwa hubungan antara pertumbuhan ekonomi dan tingkat pengangguran bernilai negatif berarti bahwa semakin tinggi pertumbuhan ekonomi maka semakin rendah tingkat pengangguran terbuka di kabupaten/kota wilayah Sarbagita. Hasil penelitian ini sejalan dengan hasil penelitian Yanti (2017) yang menyatakan bahwa variabel pertumbuhan ekonomi (PDRB) berpengaruh tidak signifikan terhadap tingkat pengangguran di wilayah Sulawesi dengan nilai koefisien bernilai negatif. Hasil penelitian Quy (2016) juga menemukan bahwa variabel pertumbuhan ekonomi mempunyai hubungan negatif dan tidak signifikan terhadap tingkat pengangguran di Vietnam. Pertumbuhan ekonomi biasanya hanya dilihat dari segi angka atau kuantitas yang tinggi tetapi tidak dilihat dari segi kualitasnya apakah ekonomi yang tumbuh tersebut berdampak terhadap masyarakat. Pertumbuhan ekonomi disebut inklusif apabila pertumbuhan ekonomi yang tumbuh tersebut mampu menurunkan kemiskinan, menurunkan ketimpangan distribusi pendapatan, dan menyerap lebih banyak tenaga kerja sehinga pengangguran akan menurun (Klasen, 2010).

\section{SIMPULAN DAN SARAN}

Berdasarkan hasil analisis dan pembahasan yang telah diuraikan sebelumnya, maka dapat ditarik kesimpulan bahwa variabel investasi, upah minimum, kontribusi sektor tersier, dan pertumbuhan ekonomi secara simultan berpengaruh signifikan terhadap tingkat pengangguran terbuka di Kabupaten/Kota Wilayah Sarbagita. Secara parsial variabel investasi berpengaruh positif dan signifikan terhadap tingkat pengangguran terbuka di Kabupaten/Kota Wilayah Sarbagita namun secara teori tidak sesuai dengan Teori Harrod Dommar yang menyatakan bahwa semakin tinggi investasi maka akan membutuhkan tenaga kerja yang semakin besar dan dapat mengurangi pengangguran. Variabel upah minimum berpengaruh negative dan signifikan terhadap tingkat pengangguran terbuka di Kabupaten/Kota Wilayah Sarbagita, secara teori hasil penelitian ini sesuai dengan teori Kurva Philips karena upah minimum yang tinggi di kabupaten/kota wilayah Sarbagita dibandingkan 
kabupaten lainnya di Provinsi Bali, ini mendorong tenaga kerja untuk semangat bekerja, sehingga berdampak pada rendahnya tingkat pengangguran yang terjadi pada daerah tersebut. Kontribusi sektor tersier dan pertumbuhan ekonomi secara parsial tidak berpengaruh (signifikan) terhadap tingkat pengangguran terbuka di Kabupaten/Kota Wilayah Sarbagita, dalam implikasi teori penelitian ini menunjukkan bahwa ternyata pergerakan indikator ketenagakerjaan tidak selalu sejalan dengan pergerakan indikator perekonomian (PDRB), dimana pertumbuhan ekonomi yang tinggi dan kontribusi sektor tersier yang berkembang pesat serta menjadi sektor utama dalam perekonomian ternyata tidak diikuti dengan penyerapan tenaga kerja yang banyak.

Berdasarkan hasil penelitian dan simpulan diatas, maka dapat diajukan saran untuk mengurangi tingkat pengangguran di Wilayah Sarbagita diharapkan pemerintah dapat membuat kebijakan yang mengarahkan investasi tidak hanya pada sektor tersier yang padat modal tetapi juga pada sektor-sektor yang padat karya. Pemerintah dapat membuat kebijakan upah minimum juga mempertimbangkan peningkatan kualitas pekerja agar memiliki daya saing tinggi dan mampu terserap dalam lapangan kerja untuk mengurangi pengangguran. Sehingga hal ini akan sejalan dengan peningkatan upah minimun yang mengurangi angka pengangguran, karena tenaga kerja (pekerja) telah memiliki kualitas yang baik. Peninjauan kembali kinerja sektor dalam kemampuannya menyerap tenaga kerja perlu diperhatikan, karena sektor yang memiliki kontribusi tertinggi pada PDRB di Wilayah Sarbagita yaitu sektor tersier ternyata penyerapan tenaga kerjanya belum optimal untuk mengurangi tingkat pengangguran, sehingga pemerintah perlu mengarahkan sektor ini menjadi padat karya dan menyerap tenaga kerja dengan lebih optimal. Dalam pembangunan khususnya di Wilayah Sarbagita menggunakan pertumbuhan ekonomi inklusif untuk melihat kualitas pembangunan sehingga pertumbuhan ekonomi yang ada dapat dinikmati oleh semua orang dan dapat mengatasi pengangguran, karena pertumbuhan ekonomi ini bukan hanya memperhatikan kuantitas tetapi berfokus pula pada kualitas SDM dalam hal ini tenaga kerja.

\section{REFERENSI}

Chang, J. J., \& Wu, C. H. (2012). Crime, Job Searches, and Economic Growth. Atlantic Economic Journal, 40(1), 3-19.

Hartanto, T. B. (2017). Analisis Pengaruh Jumlah Penduduk, Pendidikan, Upah Minimum dan Produk Domestik Regional Bruto (PDRB) Terhadap Jumlah Pengangguran di Kabupaten dan Kota Provinsi Jawa Timur Tahun 2010-2014. Jurnal Ilmu Ekonomi Terapan, 2 (1).

Indranjoto, R., \& Dewi, A. S. (2014). Pengaruh Inflasi, Pertumbuhan Ekonomi dan Investasi terhadap Pengangguran di Indonesia, 2001-2010. Eko-Regional: Jurnal Pembangunan Ekonomi Wilayah, 7(1).

Klasen, Stephen. 2010. Measuring and Monitoring Inclusive Growth: Multiple Definitions, Open Questions, and Some Constructive Proposals. Asian Development Bank Sustainable Development Working Paper Series, 12.

Margareni, N. P. A. P., Djayastra, I. K., \& Yasa, I. G. M. (2016). Faktor-Faktor Yang Mempengaruhi Kemiskinan Di Provinsi Bali. Piramida: Jurnal Kependudukan dan Pengembangan Sumber Daya Manusia, 12 (1), 101-110.

Nikolli, E. (2014). Economic Growth and Unemployment Rate: Case of Albania. European Journal of Social Science Education and Research, 1(1), 217-227.

Nurfiat, N. A., \& Rustariyuni, S. D. (2018). Pengaruh Upah dan Teknologi Terhadap Produktivitas dan Penyerapan Tenaga Kerja Pada Industri Mebel di Kota Denpasar. Piramida: Jurnal Kependudukan dan Pengembangan Sumber Daya Manusia, 14 (1), 34-48.

Prayuda, M. G., Dewi, U., \& Henny, M. (2016). Pengaruh Inflasi dan Investasi Terhadap Pengangguran di Provinsi Bali Tahun 1994-2013. E-Jurnal Ekonomi Pembangunan Universitas Udayana, 5(1), 69-95.

Quy, N. H. (2016). Relationship Between Economic Growth, Unemployment and Poverty: Analysis at Provincial Level in Vietnam. International Journal of Economics and Finance, 8(12), 113-119. 
Rahmah, D. E. (2016). Pengaruh PDRB dan Upah Minimum Terhadap Tingkat Pengangguran di Kota Surabaya Tahun 2010-2014. JEB17: Jurnal Ekonomi dan Bisnis, 1 (2), 229 - 244.

Ratih, G. A., Utama, M. S., \& Yasa, I. N. M. (2017). Pengaruh Investasi, Pengeluaran Pemerintah, Tenaga Kerja Terhadap Produk Domestik Regional Bruto dan Tingkat Kemiskinan pada Wilayah Sarbagita di Provinsi Bali. E-Jurnal Ekonomi dan Bisnis Universitas Udayana, 6(1), 29-54.

Seran, S. (2017). Hubungan antara Pendidikan, Pengangguran, dan Pertumbuhan Ekonomi dengan Kemiskinan. Jurnal Ekonomi Kuantitatif Terapan, 10(1), 59-71.

Sukirno, Sadono. (2005). Ekonomi Pembangunan. Jakarta: Raja Grafindo Persada.

Suryahadi, A., Hadiwidjaja, G., \& Sumarto, S. (2012). Economic Growth and Poverty Reduction In Indonesia Before and After The Asian Financial Crisis. Bulletin of Indonesian Economic Studies, 48(2), 209-227.

Suwandika, P. E., \& Yasa, I. N. M. (2015). Pengaruh Pendapatan Asli Daerah dan Investasi terhadap Pertumbuhan Ekonomi dan Tingkat Pengangguran di Provinsi Bali. E-Jurnal Ekonomi Pembangunan Universitas Udayana, 4(7), 794-810.

Ummatin, K. K. (2020). Pengaruh PDRB, Inflasi, dan Upah Minimum Terhadap Pengangguran Terbuka di Daerah Istimewa Yogyakarta Tahun 1987-2017. Jurnal Pendidikan dan Ekonomi, 9(3), 179-188.

Wahyuningsih, T. (2009). Analisis Penyerapan Tenaga Kerja Sektor Primer, Sekunder dan Tersier di Provinsi Maluku. IQTISHODUNA; Jurnal Fakultas Ekonomi, UIN Malang, 4(3), 1-10.

Wiwekananda, I. B. P., \& Utama, I. M. S. (2016). Transformasi Struktur Ekonomi dan Sektor Unggulan di Kabupaten Buleleng Periode 2008-2013. Jurnal Ekonomi Kuantitatif Terapan, 9(1), 37-45.

Yanti, N. F. (2017). Analisis Pengaruh Inflasi, Investasi dan PDRB Terhadap Tingkat Pengangguran di Wilayah Sulawesi Periode 2010-2014. e Jurnal Katalogis, 5(4), 139-149.

Yusuf, A. A., \& Sumner, A. (2015). Growth, Poverty, and Inequality Under Jokowi. Bulletin of Indonesian Economic Studies, 51(3), 323-348. 